\title{
KOMBINASI WAKTU DEFOLIASI ENTRES DAN MODEL SAMBUNG PUCUK TERHADAP PERTUMBUHAN BIBIT CACAO (Theobroma cacao, $\mathrm{L}$ )
}

\author{
ROSMAITI $^{*}$, DAN IWAN SAPUTRA ${ }^{1}$ \\ ${ }^{1}$ Prodi Agroteknologi Fakulktas Pertanian Universitas Samudra \\ Gampong Merandeh Langsa, Aceh Timur \\ e-mail:rosmaiti@unsam.ac.id
}

\begin{abstract}
Abstrak
Tujuan penelitian adalah untuk mendapatkan interaksi antara waktu defoliasi entres dan model sambung pucuk yang memberikan pertumbuhan bibit Cacao yang terbaik. Rancangan perlakuan terdiri dari dua faktor yaitu waktu defoliasi entres dan model sambung pucuk. Waktu defoliasi entres terdiri dari 4 waktu defoliasi yaitu, defoliasi entres pada saat penyambungan $\left(\mathrm{W}_{1}\right)$, defoliasi entres 3 hari menjelang penyambungan $\left(\mathrm{W}_{2}\right)$, defoliasi entres 6 hari menjelang penyambungan $\left(\mathrm{W}_{3}\right)$, dan defoliasi entres 9 hari menjelang penyambungan $\left(\mathrm{W}_{4}\right)$. Faktor model penyambungan diuji dua model penyambungan yaitu, sambung celah $\left(S_{1}\right)$, dan sambung diagonal $\left(\mathrm{S}_{2}\right)$. Rancangan lingkungan yang digunakan adalah rancangan acak kelompok dalam pola faktorial. Parameter pertumbuhan bibit cacao yang diamati adalah persentase bibit hidup $(\%)$, waktu mata tunas melentis (hari), panjang tunas $(\mathrm{cm})$, diameter pangkal tunas $(\mathrm{cm})$, dan jumlah daun tunas (helai). Hasil penelitian yang diperoleh adalah tidak terjadi interaksi antara kombinasi perlakuan terhadap seluruh parameter yang diamati. Waktu defoliasi entres yang terbaik adalah 9 hari menjelang penyambungan. Model defoliasi yang digunakan menunjukkan hasil yang berbeda tidak nyata.
\end{abstract}

Kata kunci : Cacao, Defoliasi, Entres, Sambung celah, sambung diagonal

\begin{abstract}
The aim of the study was to get the interaction between the time of entries defoliation and shoot grafting model that gave the best Cacao seedling growth. The treatment design consists of two factors, namely the defoliation time of the entries and the top graft model. The time of entries defoliation consists of 4 defoliation times, entres defoliation at the connection (W1), entres defoliation 3 days before connection (W2), entres defoliation 6 days before connection (W3), and entres defoliation 9 days before connection (W4). The connection factor model is tested by two connection models, namely, connecting gap (S1), and diagonal connection (S2). The environmental design used is a randomized block design in factorial patterns. Parameters of cacao seedling growth observed were the percentage of live seedlings (\%), time of shoot buds (days), shoot length (cm), shoot diameter ( $\mathrm{cm}$ ), and a number of leaf buds (strands). The results of this research are that there is no interaction between the treatment combination of all observed parameters. The best time for defoliation is 9 days before connection. The defoliation model used shows different results that are not real.
\end{abstract}

Keywords: Cacao, Defoliasi, Entres, Connect gap, connect diagonally.

Diterima:15 September 2018; disetujui 27 September 2018

Jurnal Ilmiah Pertanian, Vol. 15, No. 2, Pebruari 2019 


\section{PENDAHULUAN}

Cacao merupakan salah satu produk andalan Indonesia setelah kelapa sawit dan karet. Indonesia merupakan pemasok cacao terbesr ketiga di dunia, dan pada tahun 2014 ekspor cacao Indonesia meningkat $8.71 \%$ dibandingkan tahun 2013 (BPS, 2014). Peningkatan produksi cacao akan terus terjadi apabila teknik budidaya yang dikehendaki tanaman cacao terpenuhi.

Peningkatan produksi harus diikuti dengan penyediaan bibit yang berkualitas. Perbanyakan tanaman cacao dilakukan dengan dua cara, yaitu perbanyakan generatif dan perbanyakan vegetatif. Perbanyakan generatif membutuhkan waktu yang lama, dan perbanyakan vegetative merupakan perbanyakan yang dianjurkan untuk memenuhi kebutuhan ekspor yang terus meningkat. Waktu yang lama pada perbanyakan generative menyebabkan petani kakao di beberapa daerah pengembangan semakin menyadari kelemahan penggunaan bibit dari biji dan melakukan perbanyakan bibit secara vegetatif seperti dengan cara sambung samping, sambung pucuk, setek, dan okulasi (Limbongan dan Jufri, 2013). Limbongan dan Taufik (2011) dan Limbongan $d k k$, . (2012) melaporkan bahwa perbanyakan vegetatif menghasilkan tanaman yang secara genetik sama dengan induknya, serta tanaman memiliki produktivitas maupun mutu hasil yang seragam.

Perbanyakan tanaman secara vegetative dapat dipacu keberhasilannya dengan defoliasi daun entres sebelum digunakan. Hal ini disebabkan karena ada kaitannya dengan kandungan asimilat yang terakumulasi pada entres yang defoliasi. Akumulasi asimilat dapat merangsang pembelahan, pembesaran dan deferensiasi sel, yang kemudian mendorong proses pertautan antara batang atas dan bawah, sehingga melancarkan unsur hara dan air dari batang bawah kebatang atas (Lukman, 2004).

Defoliasi dapat mempercepat pertumbuhan tunas pada batang atas, seperti yang dilaporkan oleh Syafrison $d k k$ (2011) bahwa defoliasi entres yang dilakukan enam hari sebelum penyambungan dapat menghasilkan pertumbuhan bibit sambung pucuk kakao yang terbaik. Tanaman clover putih memperlihatkan pertumbuhan yang baik walaupun diberi perlakuan defoliasi berat (Muljanto, 1997).

Suminarti dan Novrianti, (2017) melaporkan bahwa tidak ada interaksi pada semua parameter pengamatan, pengaruh nyata terjadi akibat perlakuan defoliasi, dan pada perlakuan defoliasi menunjukkan persentase pertumbuhan tertinggi yaitu $100 \%$. "Defoliasi pada tanaman jagung memberikan pengaruh yang baik untuk tinggi tanaman dan berat 100 biji pada kacang tanah dibandingkan denga tapa perlakuan defoliasi" (Khodidjah, Kusmiadi, dan Sartika, 2014). Surtinah (2005) melaporkan bahwa akibat pemangkasan daun tanaman jagung sebelah atas yang diikuti dengan pemberian pupuk Urea menghasilkan peningkatan jumlah biji dan berat kering biji jagung. "Pada perlakuan defoliasi daun di atas dan bawah tongkol pada 77 HST atau perlakuan DAB 77 menunjukkan hasil berbeda nyata dibandingkan dengan perlakuan control (D0). Perlakuan DAB 77 berpengaruh nyata pada akhir pengamatan 109 hari setelah tanam yang mampu meningkatkan berat kering total tanaman dari 343,3 g tan-1 menjadi 392,3 g tan-1 atau dapat meningkatkan sebesar $12,49 \%$ dibandingkan D0. Pada hasil panen perlakuan DAB 77 mampu meningkatkan 6,901 t ha-1 menjadi 8,898 t ha-1 pipilan kering atau dapat meningkatkan hasil panen sebesar 22,44\% dibandingkan D0. 
Sementara viabilitas benih bertahan baik dengan lama penyimpanan selama 3 bulan dengan kadar air benih 9-12\%.(Satriyo, Widaryanto, dan Guritno, 2014)

Sambung pucuk pada jambu mete yang dilakukan dengan baik menghasilkan $89.30 \%$ bibit sambungan yang masuk dalam kategori baik (Saefudin, 2009). Tanaman manga golek yang diberi perlakuan defoliasi pada waktu disambung menghasilkan saat munculnya tunas tercepat yaitu $4.14 \mathrm{HSS}$, sedangkan manga manalagi dengan defoliasi 12 HSS, panjang tunasnya lebih panjang. Varietas harum manis 143 menghasilkan sambung jadi yang tertinggi (Muthohar, 2008). "Hasil penelitian menunjukkan bahwa saat defoliasi batang atas 12 HSS cenderung meningkatkan pertumbuhan tanaman durian hasil grafting. Akan tetapi, masingmasing perlakuan yang diberikan tidak meningkatkan persentase keberhasilan grafting durian".(Sholikah \& Ashari, 2017). Proses defoliasi dengan cara merontokkan daun pada 3 dan 6 HSS menunjukkan keberhasilan yang lebih tinggi 54.4-89.3\% dibandingkan perlakuan tanpa defoliasi yaitu13.7\%-31.3\%

\section{METODE PENELITIAN}

Penelitian ini dilaksanakan di Desa Paya Bujuk Seuleumak Kota Langsa dengan ketinggian tempat 4 - 5 meter di atas permukaan laut (dpl) (BPP, 2014). Waktu penelitian dimulaipada bulan Januari sampai dengan Maret 2018.

Bahan yang digunakan adalah entres kakao jeni klon ICCRI 01 (diperoleh dari kebun rakyat di Desa Teungku Tinggi Kecamatan Bendahara Kabupaten Aceh Tamiang), bibit kakao (diperoleh dari penangkaran bibit lampoh bijeh Kota Langsa), Fungisida Dithane M$4580 \mathrm{WP}$, bambu, paranet, plastik es lilin, tali rafia, triplek, polybag $15 \times 21$ paku, dan cat.
(Lukman, 2004). "Pelaksanaan grafting pada sore hari (W3) memperlihatkan keberhasilan pertautan sambungan lebih baik dan semakin baik lagi jika menggunakan entres yang lebih panjang $(7,5 \mathrm{~cm})$. Keberhasilan pertautan sambungan lebih tinggi jika grafting dilakukan pada sore hari dari pada pagi dan siang hari.penggunaan entres yang panjang hingga $7,5 \mathrm{~cm}$, memberikan pertautan sambungan lebih baik dibandingkan entres pendek"(Ariani, Sembiring, dan Sihaloho, 2017).

Penyambungan bibit tanaman kakao ada beberapa model yaitu model celah (baji) dan serong (cemiti). Prinsip dari kedua model sambungan ini tidak begitu berbeda, perbedaan hanya terletak pada proses pemotongan batang bawah dan entres. Yaitu pada model celah batang bawah dipotong dengan bentuk huruf $\mathrm{V}$, sedangkan pada model serong batang bawah dipotong miring atau diagonal (Aryanto, 2009). Tujuan penelitian adalah untuk mendapatkan interaksi waktu defoliasi entres dan model penyambungan terhadap keberhasilan pertumbuhan bibit cacao (Theobroma cacao. L).
Alat-alat yang digunakan dalam penelitian ini berupa cangkul, parang, meteran, gembor, hand sprayer, ember, alat tulis menulis, alat dokumentasi dan alat lainnya yang menunjang penelitian ini. Penelitian ini menggunakan Rancangan Acak Kelompok (RAK) pola faktorial, yang terdiri dari dua faktor yaitu ; Faktor waktu defoliasi entres (W) yang terdiri atas 4 taraf yaitu, $\mathrm{W}_{1}=$ defoliasi entres dilakukan saat penyambungan, $\mathrm{W}_{2}$ = waktu defoliasi entres dilakukan 3 hari sebelum penyambungan, $\mathrm{W}_{3}=$ waktu defoliasi entres dilakukan 6 hari sebelum penyambungan, $\mathrm{W}_{4}=$ lama defoliasi entres dilakukan 9 hari sebelum penyambungan. Faktor kedua adalah model penyambungan 
(S) terdiri atas 2 taraf yaitu, $\mathrm{S}_{1}=$ sambung celah, dan $S_{2}=$ sambung serong. Setiap perlakuan diulang 3 kali. Setiap unit percobaan diambil 4 bibit sebagai sampel.

Analisis data menggunakan sidik ragam (annova) pada tingkat signifikan 5 $\%$. dan dilanjutkan dengan uji Beda Nyata Jujur (BNT) taraf $5 \%$.

\section{Pelaksanaan Penelitian}

Lahan dibersihkan dari gulma yang tumbuh, dengan cara membabat, selanjutnya tanah diratakan dan dibuat plot-plot dengan menggunakan tali rafia dengan ukuran 85 x $65 \mathrm{~cm}$ dengan jarak antar plot $30 \mathrm{~cm}$ dan jarak antar blok 40 $\mathrm{cm}$.

\section{Batang Bawah}

Bibit kakao yang di gunakan dalam penelitian ini merupakan bibit kakao batang bawah varietas Criollo Bibit yang berasal dari perbanyakan secara generatif (Biji) yang sudah berumur 6 bulan. Bibit yang digunakan jenis bibit lokal yang diperoleh dari penangkaran bibit Lampoh Bijeh Kota Langsa. Bibit dipindahkan ke dalam polybag berukuran $15 \times 21 \mathrm{~cm}$ dengan media tanam yang digunakan adalah tanah top soil, pupuk kandang dan sekam padi dengan perbandingan 2: 1: 1dengan volume perpolybag $(1 \mathrm{~kg})$ dan dipelihara selama 2 minggu sebelum dilakukan penyambungan

\section{Batang Atas (Entres)}

Entres yang digunakan diambil dari pohon induk kakao jenis klon ICCRI 01 yang diperoleh dari kebun rakyat di Desa Teungku Tinggi Kecamatan Bendahara Kabupaten Aceh Tamiang. Entres dipilih berupa cabang-cabang utama (plagiotrop) yang sehat, tidak sedang bertunas (flush), warna hijau kecoklatan, dengan diameter sekitar $7 \mathrm{~mm}$.

\section{Pembuatan Naungan}

Naungan dibuat dengan kerangka dari bambu. Ukuran panjang $9 \mathrm{~m}$, lebar 3 $\mathrm{m}$ dan tinggi $2 \mathrm{~m}$ dengan atap dari paranet. Naungan dibuat bertujuan untuk mencegah penguapan air pada entres.

\section{Perlakuan}

Lama defoliasi entres dilakukan sesuai dengan perlakauan, yaitu $\mathrm{W}_{4}=$ entres di defoliasi 9 hari sebelum penyambungan kemudian dipelihara pada tanaman induk, $\mathrm{W}_{3}=$ entres di defoliasi 6 hari sebelum penyambungan kemudian dipelihara pada tanaman induk. $\mathrm{W}_{2}=$ entres di defoliasi 3 hari sebelum penyambungan kemudian dipelihara pada tanaman induk $\mathrm{W}_{1}=$ entres didefoliasi sehari sebelum penyambungan. Kemudian entres yang didefoliasi 9, 6, 3 dan sehari sebelum penyambungan dipangkas dari pohon induk lalu disimpan pada media pelepah pisang selama semalam.

Model penyambungan dilakukan sesuai dengan perlakuan, yaitu : $S_{1}=$ sambung celah, $S_{2}=$ sambung serong, dan penyambungan dilakukan pada pagi hari pukul 08.30 Wib.

Sambung baji dilakukan sebagai berikut: tanaman batang bawah pada umur 6 bulan, dipotong dengan ukuran $20-25 \mathrm{~cm}$ dari panggkal akar dan batang bawah disisa 3 helaian daun. Bagian ujung batang bawah dibelah sehingga membentuk celah menyerupai "huruf V" pada sambung baji, Pangkal entres juga disayat pada kedua sisinya hingga meruncing menyerupai huruf "V terbalik", lalu entres disisipkan ke dalam celah dengan posisi tegak lurus (dari atas ke bawah) pada batang bawah. Sedangkan pada sambung cemiti Pangkal entris juga disayat pada kedua sisinya secara miring atau diagonal yang berlawanan arah dengan potongan batang bawah, lalu entres disisipkan pada batang bawah, Pada bagian persambungan dilakukan pengikatan dengan menggunakan tali rafia dengan cara dililit dari arah bawah keatas, kemudian diletakkan kedalam plot dan disungkup dengan plastik es pada bagian 
entres yang disambung selama 3 minggu (21 HSS).

Sambung serong dilakukan sebagai berikut: Tanaman batang bawah pada umur 6 bulan, dipotong dengan ukuran 20$25 \mathrm{~cm}$ dari panggkal akar dan batang bawah disisa 3 helaian daun. Bagian ujung batang bawah penyambungan cemiti dipotong secara miring atau diagonal. Pangkal entris juga disayat pada kedua sisinya secara miring atau diagonal yang berlawanan arah dengan potongan batang bawah, lalu entres disisipkan pada batang bawah. Pada bagian persambungan dilakukan pengikatan dengan menggunakan tali rafia dengan cara dililit dari arah bawah keatas, kemudian

\section{HASIL DAN PEMBAHASAN}

Pengaruh Lama Defoliasi Terhadap Keberhasilan Sambung Pucuk Kakao Persentase Bibit Jadi (\%)

Hasil pengamatan terhadap persentase bibit jadi sambung pucuk bibit kakao dari.Hasil sidik ragam menunjukkan diletakkan kedalam plot dan disungkup dengan plastik es pada bagian entres yang disambung selama 3 minggu (21 HSS).

\section{Pengamatan}

Parameter yang diamati dalam penelitian ini antara lain : Persentase Bibit Jadi (\%), dihitung dengan rumus. $\mathrm{PBJ}=$ $\frac{\mathrm{a}}{\mathrm{b}} \times 100 \%$

Dimana : PBJ = persentase Bibit Jadi (bertaut), $a=$ Sambungan jadi (bertaut), $b$ = Jumlah bibit yang disambung ; Lama Tunas Melentis (hari); Panjang Tunas (cm); Diameter Pangkal Tunas (mm); dan Jumlah Daun (helai)

Tabel 1. Hasil Uji Rata-rata Perlakuan untuk seluruh Parameter

\begin{tabular}{lccccc}
\hline Perlakuan & Bibit jadi (\%) & $\begin{array}{c}\text { Lama melentis } \\
\text { (hari) }\end{array}$ & $\begin{array}{c}\text { Panjang tunas 60 } \\
\text { HSS }(\mathrm{cm})\end{array}$ & $\begin{array}{c}\text { Diameter } \\
\text { pangkal tunas } \\
(\mathrm{mm})\end{array}$ & $\begin{array}{c}\text { Jumlah } \\
\text { daun } \\
\text { (helai) }\end{array}$ \\
\hline $\mathrm{W}_{1}$ & $70,83 \mathrm{a}$ & 18,08 & $2,86 \mathrm{a}$ & $3,16 \mathrm{a}$ & $5,00 \mathrm{a}$ \\
$\mathrm{W}_{2}$ & $75,00 \mathrm{ab}$ & 20,08 & $3,04 \mathrm{ab}$ & $3,54 \mathrm{ab}$ & $5,13 \mathrm{ab}$ \\
$\mathrm{W}_{3}$ & $87,50 \mathrm{~b}$ & 22,25 & $3,51 \mathrm{~b}$ & $4,00 \mathrm{~b}$ & $6,25 \mathrm{~b}$ \\
$\mathrm{~W}_{4}$ & $91,67 \mathrm{~b}$ & 22,25 & $3,64 \mathrm{~b}$ & $4,15 \mathrm{~b}$ & $7,00 \mathrm{~b}$ \\
\hline BNT 0.05 & 14.15 & & 0.52 & 059 & 1.15 \\
\hline
\end{tabular}

Angka yang diikuti oleh huruf yang sama pada kolom yang sama berbeda tidak nyata pada uji BNT taraf $5 \%$.

Persentase bibit jadi tertinggi terdapat pada perlakuan $\mathrm{W}_{4}$ (defoliasi entres dilakukan 9 hari sebelum penyambungan) sedangkan yang terendah terdapat pada perlakan $\mathrm{W}_{1}$ (lama defoliasi entres dilakukan saat penyambungan). Uji BNT perlakuan $\mathrm{W}_{4}$ berbeda nyata dengan perlakuan $\mathrm{W}_{1}$ tetapi berbeda tidak nyata dengan perlakuan $\mathrm{W}_{2}$ dan $\mathrm{W}_{3}$ serta antara perlakuan $\mathrm{W}_{1}$ dan $\mathrm{W}_{2}$ juga tidak berbeda nyata. Hal ini diduga defoliasi pada entres bahwa lama defoliasi berpengaruh nyata terhadap persentase bibit jadi tanaman kakao.Rata - rata persentase bibit jadi tanaman kakao akibat perlakuan lama defoliasi dapat dilihat pada Tabel 1 .

sangat mempengaruhi keberhasilan dalam penyambungan bibit kakao. Karena defoliasi entres akan meningkatkan kandungan asimilat pada entres. Akumulasi asimilat akan merangsang pertumbuhan dan diferensiasi sel untuk pembentukan jaringan baru di daerah pertautan sambungan sehingga meningkatkan persentase sambungan jadi. Sesuai dengan pendapat Lukman (2004) yang menyatakan bahwa perlakuan 
defoliasi entres dapat mendukung persentase sambung jadi karena berkaitan dengan kandungan asimilat yang terakumulasi pada entres yang didefoliasi. Akumulasi asimilat dapat merangsang pembelahan, pembesaran dan deferensiasi sel, yang kemudian mendorong proses pertautan antara batang atas dan bawah.

\section{Lama Tunas Melentis (hari)}

Hasil pengamatan terhadap lama tunas melentis sambung pucuk bibit kakao disajikan pada Lampiran 3,sedangkan analisis sidik ragam disajikan pada Lampiran 4.Hasil analisis sidik ragam menunjukkan bahwa lama defoliasiberpengaruh tidak nyata terhadap waktu tunas melentis bibit kakao. Hasil analisis sidik ragam menunjukkan bahwa waktu defoliasi berpengaruh tidak nyata terhadap lama tunas melentis. Hal ini diduga taraf waktu defoliasi yang kurang berfariasi sehingga pada parameter lama tunas melintis menunjukan hasil yang tidak berpengaruh nyata. Oleh karena itu perlu dilakukan penelitian lanjutan dengan taraf lama defoliasi yang lebih berfariasi.

\section{Panjang Tunas (cm)}

Hasil pengamatan terhadap panjang tunas sambung pucuk bibit kakao berdasarkan sidik ragam menunjukkan bahwa lama defoliasi berpengaruh sangat nyata terhadap panjang tunas bibit kakao pada umur 60 HSS. Panjang tunas yang tertinggi terdapat pada perlakuan $\mathrm{W}_{4}$ (defoliasi entres dilakukan 9 hari sebelum penyambungan). Hasil uji BNT $\mathrm{W}_{4}$ berbeda nyata dengan perlakuan $\mathrm{W}_{1}$, Hal ini diduga defoliasi entres akan menurunkan kandungan hormon auksin dan memacu pembentukan hormon sitokinin pada entres yang didefoliasi. Hormon sitokinin berperan merangsang pembelahan dan pembesaran sel. Jumlah dan ukuran sel yang bertambah akan mengakibatkan tunas bertambah panjang.

\section{Diameter Pangkal Tunas (mm)}

Hasil pengamatan terhadap diameter pangkal tunas sambung pucuk bibit kakao berdasarkan sidik ragam menunjukkan bahwa lama defoliasi berpengaruh sangat nyata terhadap diameter tunas bibit kakao pada umur 60 HSS.

Diameter tunas tertinggi akibat perlakuan lama defoliasi tertinggi dijumpai pada umur 60 HSS $\mathrm{W}_{4}$ berbeda nyata dengan perlakuan $\mathrm{W}_{1}$ tetapi tidak berbeda nyata dengan perlakuan $\mathrm{W}_{2}$ dan $\mathrm{W}_{3}$. Hal ini diduga proses defoliasi mampu mengarahkan translokasi fotosintat dan mengatur keseimbangan hormon untuk merangsang pertumbuhan sambungan. Hal ini disebabkan karena ada kaitannya dengan kandungan asimilat yang terakumulasi pada entres yang defoliasi. Akumulasi asimilat dapat merangsang pembelahan, pembesaran dan deferensiasi sel, yang kemudian mendorong proses pertautan antara batang atas dan bawah, sehingga melancarkan unsur hara dan air dari batang bawah kebatang atas. Hal ini sejalan dengan Widianto (2000) defoliasi pada entres telah membuang proses asimilat, juga meniadakan hormon pertumbuhan tunas yang biasanya ditranslokasikan dari daun, sehingga dapat mempertinggi sambungan jadi dan mepercepat pembentukan tunas.

\section{Jumlah Daun (Helai)}

Hasil pengamatan terhadap jumlah daun sambung pucuk bibit kakao dan .Hasil sidik ragam menunjukkan bahwa lama defoliasi berpengaruh sangat nyata terhadap jumlah daun bibit kakao pada umur 60 HSS. Hasil uji BNT pada 60 HSS $\mathrm{W}_{4}$ berbeda nyata dengan perlakuan $\mathrm{W}_{1}$ tetapi tidak berbeda nyata dengan $\mathrm{W}_{2}$ dan $\mathrm{W}_{3}$ Hal ini diduga defoliasi entres yang terlalu awal mengakibatkan pertumbuhan batang atas terlalu cepat. Pertumbuhan batang atas yang terlalu cepat akan memerlukan asimilat yang 
banyak sementara pertautan sambungan belum sempurna sehingga terjadi gangguan translokasi asimilat. Akibatnya pertumbuhan tunas dan daun sambungan menjadi terganggu. Sebaliknya defoliasi entres yang terlambat akan mengakibatkan batang atas tumbuh lebih lambat. Defoliasi entres pada saat yang optimal berkaitan erat dengan keserasian laju tumbuh batang atas dengan batang bawah sehingga tercipta kompatibilitas pertumbuhan. Sejalan dengan pendapat Hartman et al. (1997) yang menyatakan bahwa jika terjadi inkompatibilitas sambungan mengakibatkan pertumbuhan tunas terganggu atau bahkan mati. Pertumbuhan tunas erat kaitannya dengan jumlah daun sambungan.

\section{Pengaruh Tipe Panyambungan Terhadap Keberhasilan Sambung Pucuk Kakao \\ Persentase Tumbuh dan lama tunas melintis (\%)}

Hasil pengamatan terhadap persentase bibit jadi sambung pucuk bibit kakao dan waktu tunas melintis berdasarkan sidik ragam menunjukkan bahwa model penyambungan berpengaruh tidak nyata terhadap persentase bibit jadi dan lama tunas melintis.

Tabel 2. Rata - rata persentase bibit jadi dan lama tunas melintis akibat perlakuan tipe penyambungan $(\%)$

\begin{tabular}{l|c|c|c|c|c}
\hline Perlakuan & $\begin{array}{l}\text { Persentase } \\
\text { bibit jadi (\%) }\end{array}$ & $\begin{array}{l}\text { Lama tunas } \\
\text { melintis (hari) }\end{array}$ & $\begin{array}{l}\text { Panjang tunas } \\
(\mathrm{cm})\end{array}$ & $\begin{array}{l}\text { Diameter tunas } \\
(\mathrm{mm})\end{array}$ & $\begin{array}{c}\text { Jumlah daun } \\
\text { (helai) }\end{array}$ \\
\hline $\mathrm{S}_{1}$ & 85,42 & 21,23 & $3,47 \mathrm{~b}$ & 3,85 & 6,08 \\
$\mathrm{~S}_{2}$ & 77,08 & 20,10 & $3,06 \mathrm{a}$ & 3,57 & 5,60 \\
\hline BNT 0.05 & tn & th & 0.37 & tn & tn \\
\hline
\end{tabular}

Angka yang diikuti oleh huruf yang sama pada kolom yang sama berbeda tidak nyata pada uji BNT taraf $5 \%$.

Persentasi bibit jadi keseluruhan pada perlakuan S1 (sambung celah) dengan nilai $(85,42)$. Hal ini diduga kedua model yang dicobakan (sambung celah, sambung serong) dapat mempertaut bagian tanaman yang disambung (entres dan batang bawah) meskipun tingkat keberhasilannya beragam. Keberhasilan pertautan dari bagian tanaman yang disambung ditentukan oleh kemampuan sel atau jaringan pada bagian yang dipertaut dalam membentuk sel-sel atau jaringan fungsional. Tambing dan Hadid (2003) menjelaskan bahwa proses pertautan pada bagian tanaman yang disambung diawali oleh respons sel atau jaringan pada bagian yang terluka (bagian sambungan). Pelukaan (pengirisan) pada jaringan tanaman yang disambung menyebabkan sejumlah sel-sel parenchyma (pada entres dan batang bawah) rusak dan mati.

Model penyambungan berpengaruh tidak nyata terhadap lama tunas melentis. Hal ini dikarnakan bahwa bibit yang sudah bertaut sudah mulai mengalami proses metabolisme dan pembelahan sel sehingga model penyambungan tidak menunjukkan pengaruh yang nyata antar perlakuan yang diuji. Hasil analisis sidik ragam menunjukkan bahwa waktu penyambungan berpengaruh tidak nyata terhadap lama tunas melentis. Hal ini dikarnakan bahwa bibit yang sudah bertaut sudah mulai mengalami proses metabolisme dan pembelahan sel sehingga waktu pelaksanaan penyambungan tidak menunjukkan pengaruh yang nyata antar perlakuan yang diuji. Susilo dan Sobadi (2008) melaporkan bahwa kompatibilitas penyambungan merupakan interaksi yang terjadi antara batang bawah dengan batang atas yang berpengaruh terhadap pertumbuhan bibit. Terjadinya pembengkakan sejak awal pada daerah pertautan tidak menghambat pertumbuhan bibit. Pertautan bibit tersebut akan mendukung pertumbuhan bagian atasnya. Manurut Riodevriza (2010) sel-sel kambium bersifat meristematis yang 
berarti mampu membelah membentuk sel baru yang meningkat pertumbuhan tanaman.

\section{Panjang Tunas (cm)}

Hasil pengamatan terhadap panjang tunas sambung pucuk bibit kakao menunjukkan bahwa model penyambungan berpengaruh nyata terhadap panjang tunas bibit kakao pada 60 HSS. Hal ini diduga panjang tunas pada tanaman kakao dengan perlakuan $S_{1}$ (Sambung celah) menunjukkan hasil yang lebih baik, hal ini dikarenakan adanya hormon auksin dan sitokinin endogen pada tanaman yang sudah mampu mempengaruhi proses pembelahan sel dan pemanjangan sel. Hal ini sejalan dengan pendapat Lakitan (2001) bahwa pertumbuhan panjang tunas dipengaruhi oleh hormon auksin dan sitokinin. Sitokinin akan merangsang pembelahan sel melalui peningkatan laju sintesis protein, sedangkan auksin akan memacu pemanjangan sel-sel yang menyebabkan pemanjangan batang

\section{Diameter Tunas (mm)}

Diameter tunas sambung pucuk bibit kakao menunjukkan bahwa tipe penyambungan berpengaruh tidak nyata terhadap diameter tunas bibit kakao pada umur 60 HSS. Hal ini diduga bahwa diameter tunas pada penyambungan sambung celah menghasilkan kompatibilitas antara batang bawah dan batang atas yang lebih baik sebelum waktu pengamatan, sehingga dapat meningkatkan pertumbuhan diameter tunas setelah proses penyambungan itu terjadi pada waktu selanjutnya. Hal tersebut sesuai dengan pendapat Pina dan Errea (2005) menyatakan tahapan terjadinya kompatibilitas penyambungan diawali dengan terbentuknya sel-sel parenkim yang akan menghubungkan jaringan batang atas dengan jaringan batang bawah kemudian kalus terdeferensiasi menjadi jaringan pengangkut (phloemdanxylem). Kompatibilitas penyambungan terjadi apabila jaringan pengangkut tersebut dapat berfungi secara baik untuk menghubungkan jaringan bawah dengan batang atas. Hartman (1990) dalam Sari dan Susilo (2012), menyatakan bahwa jika pertemuan kambium dari batang atas dan batang bawah dalam penyambungan semakin banyak maka penyambungan akan semakin berhasil, dan dalam kasus ini berbeda tidak nyatanya Diameter tunas pada 60 HSS disebabkan karena sambungan sudah terjadi sebelum 60 HSS.

\section{Jumlah Daun (Helai)}

Hasil analisis sidik ragam menunjukkan bahwa tipe penyambungan berpengaruh tidak nyata terhadap jumlah daun bibit kakao umur 60 HSS. Hal ini diduga bahwa tipe penyambungan lebih berpengaruh kepada tingkat panjang tunas dan diameter tunas, sehingga pertumbuhan daun bibit kakao hasil sambung tidak dipengaruhi oleh model penyambungan, tetapi lebih dipengaruhi oleh faktor lingkungan yaitu unsur hara dan air.

Soegito dan Rebin (2002, dalam Satrio (2014), menambahkan keberhasilan sambungan akan memacu transformasi unsur hara dan air ke seluruh bagian tanaman batang atas yang akan mempengaruhi komponen pertumbuhan lainnya seperti daun dan tinggi tanaman.

\section{KESIMPULAN}

Waktu defoliasi terbaik diperoleh pada perlakuan $\mathrm{W}_{4}$ (waktu defoliasi entres dilakukan 9 hari sebelum penyambungan).
Model penyambungan yang terbaik adalah perlakuan $S_{1}$

(sambung celah). Kombinasi kedua perlakuan tidak memberikan interaksi 
terhadap pertumbuhan bibit ccao pada umur 60 HSS.

\section{DAFTAR PUSTAKA}

Ana, P., dan Errea, P., 2005. A review of new advances in mechanism of graft compatibility-incompatibility in Scientia Horticulturae 106(1):1-11.

Ariani, S. B., Sembiring, D. S. P. S., \& Sihaloho, N. K. (2017). Keberhasilan Pertautan Sambung Pucuk Pada Kakao (Theobroma cacao L) Dengan Waktu Penyambungan Dan Panjang Entres Berbeda. Jurnal Agroteknosains, 1(2), 87-99.

Aryanto, dan Polakitan, D., 2009. Uji produksi rumput dwarf (Penisetumpurpureum CV Dwarf). Jurnal Ilmiah, Balai Pengkajian Teknologi Pertanian Sulawesi Utara, Jl. Kampus Pertanian Kalasey.

BPS, 2004. Aceh Dalam Angka. Badan Pusat Statistik. Banda Aceh.

Hartmann, H.T., D.E. Kester, F.T. Davies, Jr, R.L. Geneve. 1997. Plant Propagation: Principles and Practices. 7th edition. Prentice Hall Inc. 770p.

Khodijah, N.S., Kusmiadi, R., dan Sartika, S., 2014. Optimalisasi Produksi Kacang Tanah Dan Jagung Pada Pola Tanam Tumpangsari Dengan Perlakuan Defoliasi Jagung. Enviagro, Jurnal Pertanian dan Lingkungan, Vol. 7(2): 1-48

Lakitan, B. 2001. Fisiologi Tumbuhan dan Perkembangan Tanaman.Raja. Jakarta.

Limbongan, J. 2011. Kesiapan penerapan teknologi sambung samping (sidecleft-grafting) untuk mendukung program rehabilitasi tanaman kakao. Jurnal Penelitian dan Pengembangan Pertanian 30(4): 156-163.

Limbongan, J., B.A. Lologau, B. Nappu, G. Thahir, dan N. Lade. 2012. Peningkatan mutu bibit kakao asal grafting dan somatik embriogenesis di Sulawesi Selatan. Laporan Insentif Peningkatan Kemampuan Peneliti dan Perekayasa Kementerian Riset dan Teknologi bekerja sama dengan Balai Pengkajian Teknologi Pertanian Sulawesi Selatan, Makassar.

Limbongan dan Dhufri, F., 2013. Pengembangan Teknologi Sambung Pucuk Sebagai Alternatif Pilihan Perbanyakan Bibit Kakao. J. Litbang Pert. Vol. 32 (4): 166-172).

Lukman, W. (2004). Teknik Sambung Pucuk Menggunakan Stadium Entres Yang Didefoliasi Pada Jambu Mete Wawan Lukman 1. Buletin Teknik Pertanian, 9(3), 13-15.

Muljanto, D. (1997). Perubahan Ultrastruktur Dan Kemampuan Merestorasi Bintil Akar Tanaman Clover Putih (Trifolium repens L) Akibat Defoliasi Berat. J. Ilmu Pertanian, 6(1), 1-7.

Muthohar, F. B. (2008). Respon Beberapa Varietas Entres Mangga ( Mangifera Indica L ) Pada Perbedaan Waktu Defoliasi Terhadap Pertumbuhan Bibit Secara Grafting. JIPTUMMPP, (April 2006), 3-4.

Riodevriza (2010). Pengaruh Umur Pohon Induk terhadap Keberhasilan Stek dan Sambungan Shorea selanica BI. Departemen Silvikultur. Fakultas Kehutanan Institut Pertanian Bogor. Bogor.

Saefudin, dan Ferri, Y., 2009. Pengaruh Panjang Entres Terhadap Keberhasilan Sambung Pucuk Dan Pertumbuhan Benih Jambu Mete. Buletin RISTRI Vol 2 (2):121-124.

Sari, I.A. and A.W. Susilo. 2012. Keberhasilan sambungan pada 
beberapa jenis batang atas dan famili batang bawah kakao (Theobroma cocoa L.). Pelita Perkebunan (a Coffee and Cocoa Research Journal), 28(2). pp.72-81.

Satriyo, T. A., Widaryanto, E., \& Guritno, B. (2014). Hasil Dan Mutu Benih Jagung ( Zea mays L .) Var . Bisma The Impact Of Position And Time Leaf Defoliation On The Growth , Yield And Seed Viability Of Corn ( Zea mays L .) Var . Bisma. Jurnal Produksi Tanaman, 4(4), 256-263.

Syafrison dkk. 2011. Pengaruh saat defoliasi entres tehadap pertumbuhan sambung pucuk kakao (Theobroma cacao L) dengan batang bawah yang mempunyai jumlah daun yang berbeda . Padang

Sholikah, A., \& Ashari, S. (2017). Pengaruh Saat Defoliasi Batang Atas Terhadap Pertumbuhan Dan Keberhasilan Grafting Durian ( Durio zibethinus Murr .). Jurnal Produksi Tanaman, 5(3), 441-450.

Subandi A (2008) Metabolisme. http://metabolisme.blogs. pot.com/2007/09. Diakses pada 29 April 2018

Sudjijo, 2008. Pengaruh Ukuran Batang Bawah dan Batang Atas terhadap Pertumbuhan Durian Monthong, Hepe, dan DCK-01. J. Hort. Vol. 19 (1): 89-94.

Suminarti, N. E., \& Novrianti, R. (2017). Pengaruh Defoliasi Dan Posisi Penanaman Stek Batang Pada Pertumbuhan Dan Hasil Tanaman Ubi Jalar (Ipomoea batatas L.) Lam. Var. Sari. Jurnal Biodjati, 2(1), 2129.

Surtinah, S. (2005). Hubungan Pemangkasan Organ Bagian Atas Tanaman Jagung (Zea mays, L) Dan Dosis Urea Terhadap Pengisian Biji. Jurnal Ilmiah Pertanian, 1(2), 27-36.

Tambing, Y., dan Hadid, A. 2003. Keberhasilan pertautan sambung pucuk pada mangga dengan waktu penyambungan dan panjang entris berbeda. Agroland, 15(4). 